\title{
Bryophyte diversity patterns in flooded and tierra firme forests in the Araracuara Region, Colombian Amazonia
}

\author{
Juan C. Benavides ${ }^{1-3}$, Alvaro Idarraga ${ }^{2}$ \& Esteban Alvarez ${ }^{1}$ \\ 1-Tropenbos-Colombia. A.A. 036062, Bogota D.E. Colombia. \\ 2- Herbarium, Institute of Biology, University of Antioquia. AA. 1226 Medellín - Colombia. \\ 3-e-mail: jcbd@epm.net.co
}

\begin{abstract}
We investigated patterns of bryophyte species richness and composition in two forest types of Colombian Amazonia, non-flooded tierra firme forest and floodplain forest of the Caquetá River. A total of 109 bryophyte species were recorded from 140.2 ha plots. Bryophyte life forms and habitats were analyzed, including the canopy and epiphylls. Bryophyte species did not show significant differences between landscapes but mosses and liverworts were different and with opposite responses balancing the overall richness. Independence test showed differences in both life form and habitat use distribution between the two forest types with more fan and mat bryophytes species in the floodplains, and more epiphytic liverworts in the tierra firme forest. Correspondence analysis showed differences in the bryophyte species assemblage between the two forest types where they may be responding to the higher humidity provided by the flooding. Despite of, the environmental differences detected, epiphyll species assemblages were not strongly affected. Apparently, epiphyll habitat is stressful enough to hide the environmental differences between the flooded and Tierra firme forests.
\end{abstract}

Resumen: Investigamos los patrones de riqueza de especies y composición florística de briofitos en dos tipos de bosque en la Amazonía Colombiana. Bosques no inundados de Tierra firme y bosques periódicamente inundados en los planos inundables del Rió Caquetá. Encontramos 109 especies de briofitos en 14 parcelas de 0.2 ha. Nosotros analizamos diferencias en la distribución de formas de vida y hábitat de los briofitos entre los dos tipos de bosque incluyendo especies del dosel y epifilas. El número de especies de briofitos no mostró diferencias significativas entre los dos tipos de bosque. Pero musgos y hepáticas si tuvieron diferencias con respuestas opuestas balanceando el número total de especies. Pruebas de independencia mostraron diferencias en la distribución de formas de vida y uso de hábitat entre los dos tipos de bosque con más especies de abanicos y esteras en los planos inundables, y más especies de hepáticas epifitas en el bosque de Tierra firme. El análisis de correspondencia mostró diferencias en la composición florística de briofitos entre ambos tipos de bosque, donde las comunidades de briofitos pueden estar respondiendo a un gradiente de humedad aportada por la inundación periódica de los planos inundables. La composición florística de los briofitos epifilos no mostró una separación tan clara entre los tipos de bosque como si fue detectada en los otros hábitat donde los briofitos fueron encontrados. Aparentemente, el hábitat epifilo es suficientemente estresante para ocultar el efecto de las diferentes condiciones ambientales de los bosques inundables y de Tierra firme. 


\section{Introduction}

Bryophytes in tropical lowland rain forest have an important role in water and nutrient cycles, mainly in the incorporation of atmospheric $\mathrm{N}$ and P(Clark et al. 1998, Hietz et al. 2002). They promote the establishment of vascular epiphytes providing suitable substrates in the trees (Zotz $\&$ Vollrath 2003) and regulate the microclimatic conditions inside the forests (Stuntz et al. 2002). Tropical lowland rain forests, because of their forest complexity and variety of microhabitats, have high bryophyte diversity (Gradstein 1992a). Ecological data of bryophytes on lowland rain forest are almost lacking, particularly in the Amazon basin where large portions remained unexplored (Gradstein 1992b). However, information on taxonomy and distribution of tropical lowland forest bryophytes has increased during the last years providing tools for reliable identifications (Churchill 1994, Gradstein et al. 2001, Gradstein \& Costa 2003). Thus, a better understanding of bryophyte responses to environmental gradients in tropical forests has been achieved (Acebey et al. 2003). Mosses and liverworts have been considered affected evenly by environmental conditions. However, they have shown different responses in tropical forests. For instance in altitudinal gradients the peaks in species richness of mosses is rather lower than in liverworts (Kessler 2000), and mosses also have shown a higher specialization than liverworts in lowland rain forests (Florschütz-de Waard \& Bekker 1987).

Bryophyte species richness has a direct relationship with humidity factors (Bates 2000). Particularly, the humid and shaded conditions of the understory in tropical lowland rain forests favor bryophyte growth (Pócs 1982). The moisture availability also has an effect on bryophyte life forms because of bryophyte life forms reflect different strategies to avoid water stress and to maximize photosynthesis (Mägdefrau 1982, Richards 1984). Tropical lowland bryophytes are found in a variety of habitats such as forest canopy (sun epiphytes), tree trunk and base (shaded epiphytes), rotten wood, fallen leaves, soil, stones on outcrops and leaves of vascular plants (epiphylls). Bryophyte species composition changes based on differences in physical and chemical conditions (Gradstein \& Pócs 1989). Particularly, lowland mosses have shown lower tolerance to drought than liverworts and exhibit a preference for humid habitats such as rotten wood and tree bases (Florschütz-de Waard \& Bekker 1987). Explanations remain obscure; perhaps liverworts avoid water stress more effectively by their fastendosporic germination and the presence of morphological features such as water sacs, smooth mat life forms and rhizoidal discs (Gradstein \& Pócs 1989). Even more, bryophyte species assemblages have been related with forest structure (Richards 1984), which is strongly related with microclimatic conditions and habitat availability inside the forests (Parker 1995). Differences in structure and composition have also been found in the forests of northwestern Amazonia where several forest types have been documented. These different forest types belong to landscape units and they are the result of differences in flooding, edaphic characteristics and drainage quality (Duivenvoorden \& Lips 1995).

The present paper is concerned with the changes in bryophyte composition and species richness between a floodplain and a tierra firme forest. The field study was carried out in the middle Caquetá region in the central part of the Colombian Amazon. Despite of, the differences in forest structure and composition between floodplain and tierra firme forests evidenced in previous studies (Londoño \& Alvarez 1997), information comparing their bryophyte communities has not been done so far (Churchill 1994).

\section{Methods}

Study area: The study was conducted in the lowland tropical forest of the Aracuara region $\left(0^{\circ} 37^{\prime} \mathrm{S}, 72^{\circ} 24^{\prime} \mathrm{W}\right)$ in the middle Caquetá area of the Colombian Amazon (Fig. 1). Mean annual temperature and annual rainfall are about $25^{\circ} \mathrm{C}$ (1980-1989) and $3060 \mathrm{~mm}$ (1979-1990) respectively (Lips \& Duivenvoorden 2001). Two main landscape units in the Amazon forest were studied: floodplains of the Caquetá River and 


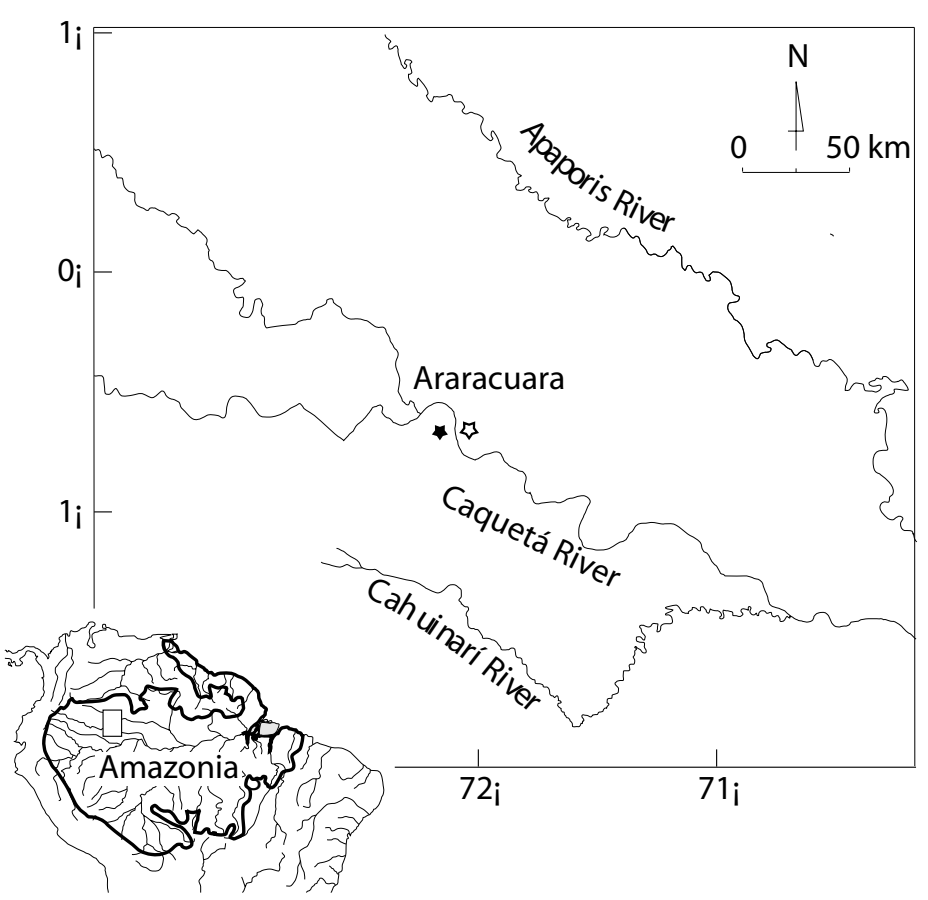

Figure 1. Map of the Amazon region showing the ubication of the Aracuara

región in the middle Caquetá area. Black mark represent location of

floodplain 1.8 ha plot and white mark plot in the Tierra Firme forest plot.

tierra firme forests in the Tertiary sedimentary plain. The floodplain forests or varzea forests of white water rivers are characterized by periodical flooding providing continuous input of nutrients from the Andes region. These forests have tall trees with a low understory density. In contrast, the tierra firme forests in the tertiary sedimentary plain never are flooded. A dense understory and a high tree density are characteristic of this landscape unit (Londoño \& Alvarez 1997, Duque et al. 2001).

Survey methods: Bryophyte collections were made in 14 transects of 0.02 ha $(50 \times 4 \mathrm{~m})$. The 14 transects were located inside of two 1.8 ha plots previously demarked and located in tierra firme and floodplain forests, respectively (Londoño \& Alvarez 1997). Six transects were located in the floodplain and 8 in the tierra firme forest. All the bryophyte colonies observed along transects were collected. The habitat (substrate) and life form following Bates (1998) of all bryophytes collected were recorded in the field. Epiphytic bryophytes were collected following the Johanson's zonation of forest trees: tree base, trunk, inner branches, outer branches and twigs (Nieder \& Zotz 1998). At least 4 trees in each transect were completely surveyed where collections made in the higher strata of the forest were done with the help of indigenous climbers. Bryophytes were also collected on termite nests, rotten wood, fallen leaves, soil and leaves of vascular plants (epiphylls). Bryophyte collections were stored in the HUA herbarium at the University of Antioquia. The nomenclature follows Uribe \& Gradstein (1998) for liverworts and Crosby et al. (1992) for mosses. 


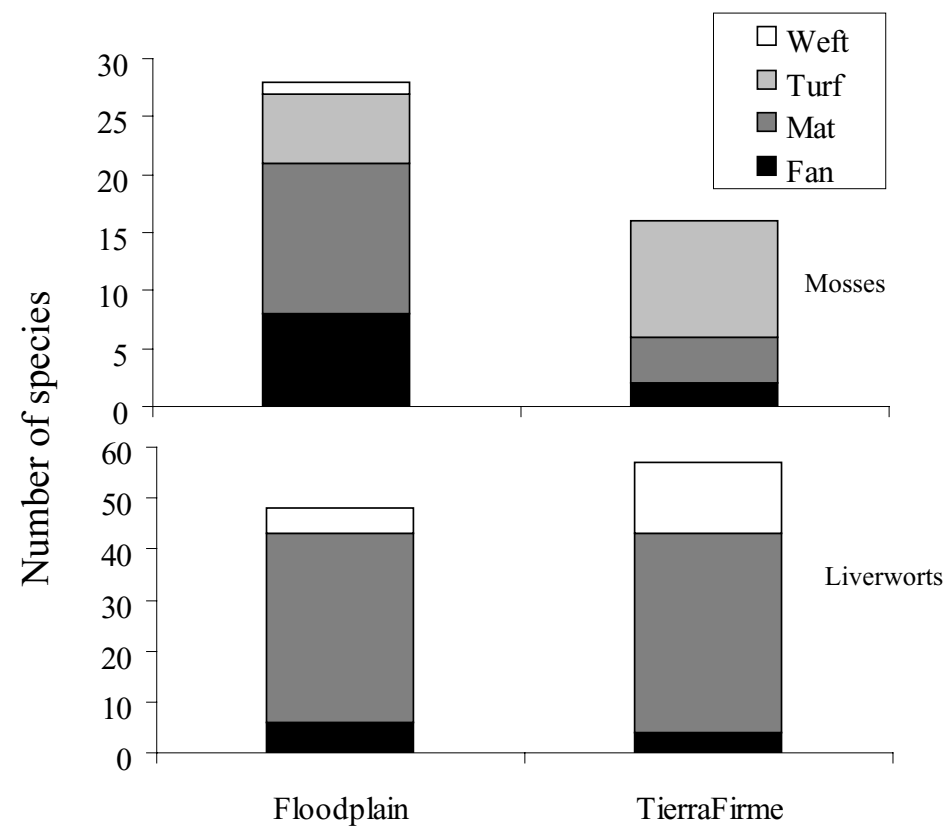

Figure 2. Distribution of mosses (bottom) and liverworts (above) life forms in Tierra Firme and Floodplain forests in the Aracuara region.

Data analysis: Our data set of bryophyte species presence in the 0.02 ha plots was used in analysis of spceis composition and richness. Bryophyte species richness was compared between the two landscape units. Comparisons were made by Mann-Whitney U test for two independent samples. To verify if the habitat and life form species distribution was independent between the landscapes units a G-test of independence was performed. The $\mathrm{G}$ test of independence examines if the life form proportions are different between the landscape units (Sokal \& Rohlf 1995). The analyses described above were made using SPSS statistical software for windows (Release 11.0.1, SPSS Inc. 2001).

Bryophyte composition patterns were analyzed with a principal coordinate analysis ( $\mathrm{PCoA})$. The principal coordinate analysis is a method to identify the main trends in the transects (objects) with respect to the species patterns (descriptors) by means of an Euclidean representation of the transects (objects) relationships measured with the Jaccard similarity Index (Legendre \& Legendre 1998). Because the PCoA analysis requires a distance matrix, the original Jaccard similarity matrix was transformed to distances by simple subtraction $(\mathrm{D}=1-\mathrm{S})$. The $\mathrm{PCoA}$ analysis was made using the R-Package for Macintosh (Casgrain \& Legendre 2002).

\section{Results}

109 bryophyte species (77 liverworts, 32 mosses) were identified. The number of species between the floodplain and the tierra firme forests did not differ significantly $(\mathrm{M}-\mathrm{W} \mathrm{U}=16, \mathrm{p}=0.32)$. However, more moss species were present in the floodplains (M-W U $=0.5, \mathrm{p}=0.002$ ) (Table 1). The distribution of bryophyte life forms was associated with forest type (Chi-sq $=7.8, \mathrm{p}=0.05)$. Differences were also detected in mosses (Chi$\mathrm{sq}=7.8, \mathrm{p}=0.5)$ and liverworts $(\mathrm{Chi}-\mathrm{sq}=6.7$, $\mathrm{p}=0.08$ ). More species of mosses and liverworts 


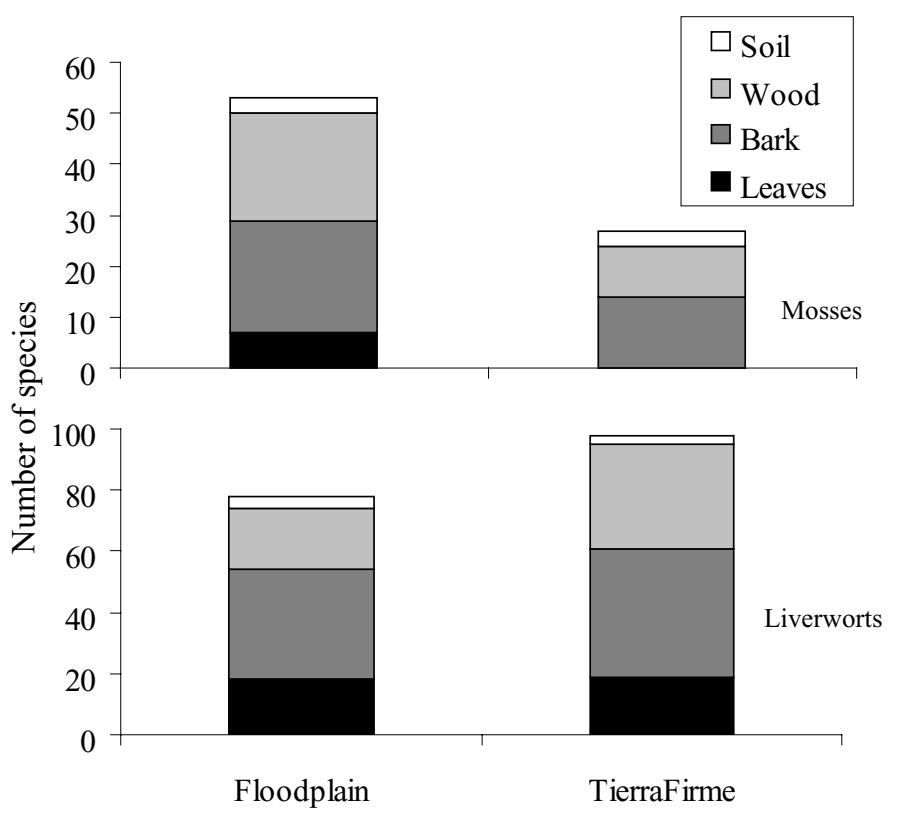

Figure 3. Moss (bottom) and liverwort (above) species habitat distribution in Tierra Firme and Floodplain forests in the Aracuara region.

were found growing as turfs in the tierra firme forest and more moss species growing as fans and mats were found in the floodplain forest (Fig. $2)$. Epiphytic species were clumped together without differences in height zone. Because of the predicted altitudinal zonation of bryophytes along the tree height was not documented. The bryophyte species richness was different among the four habitats differentiated with more epiphyte species than in the remaining habitats (leaves, rotten wood and soil) (Fig. 3). However, independence test did not detect an association of bryophyte habitat with forest type (Chi-sq=0.9, $\mathrm{p}=0.8)$. However mosses $(\mathrm{Chi}-\mathrm{sq}=10.2, \mathrm{p}<0.5)$ and liverworts $(\mathrm{Chi}-\mathrm{sq}=4.7, \mathrm{p}=0.076)$ showed differences in their habitat distribution in the two forests. Epiphyllic mosses were only found in the floodplain forest and wood-covering liverwort species were more frequent in the tierra firme forest (Fig 3).

The PCoA diagram showed a separation between the bryophyte assemblages of the rain forests of the floodplains and the tierra firme (Fig. 4). The differences were also observed between mosses and liverworts. However, the species assemblages of epiphylls only showed a small variation along the theoretical gradient (Fig. 5). Change in bryophyte species were mainly observed in epiphytic mosses of Neckeraceae and Pilotrichaceae including hanging species of Zelometeorium and Squamidium. They were found almost exclusively in the floodplain forest, together with hygrophytic liverwort species of the genera Metzgeria and Plagiochila. Species of Bazzania and almost all species of Drepanolejeunea were only found as epiphytes in the tierra firme forest together with species of the turf forming moss Syrrhopodon (Table 2).

\section{Discussion}

The number of species recorded in the study area (109) is almost similar to the 122 species reported in two similar landscape units in the Surinam rain forests (Florschütz-de Waard \& Bekker 1987). 


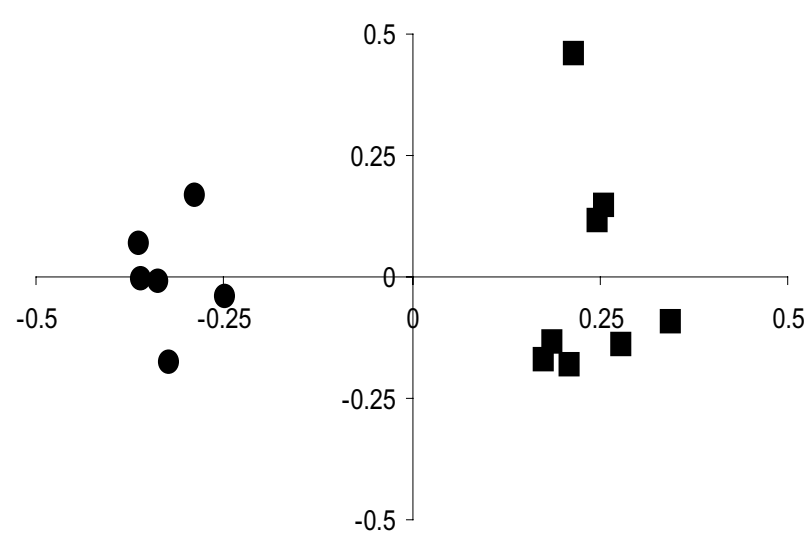

Figure 4. Ordination diagram of PCoA analysis of bryophyte species collected in 14 plots in the floodplains of the Caqueta River (Squares) and Tierra Firme forests (Circles) in the Araracuara region, Northwestern Colombian Amazon.

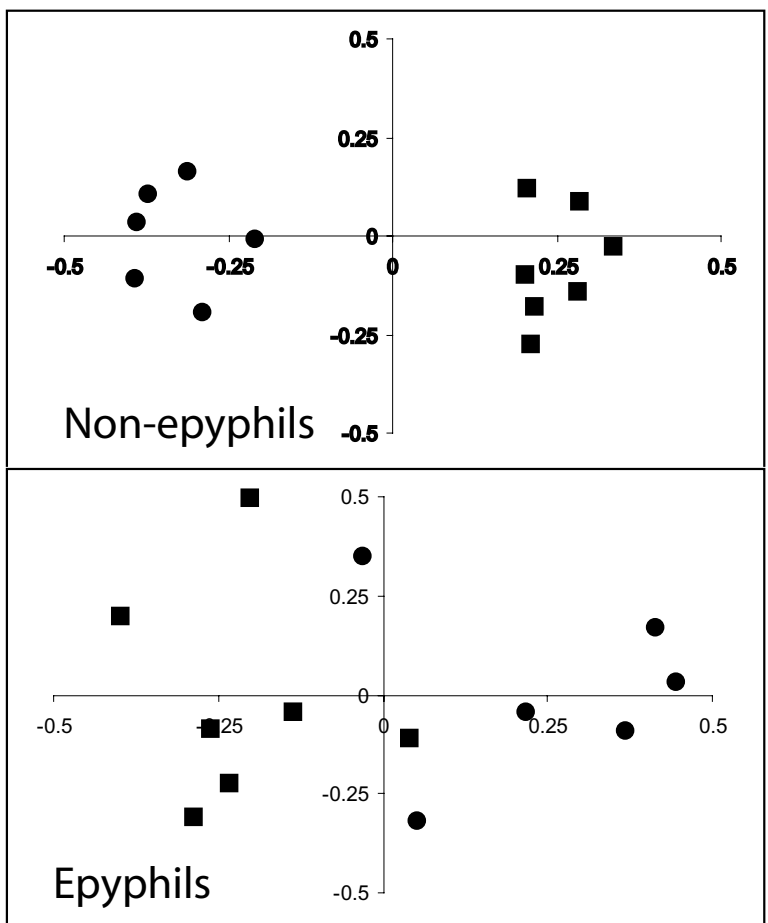

Figure 5. Ordination diagram of PCoA analysis of epiphyll bryophytes collected in 14 plots in the floodplains of the Caqueta River (Squares) and Tierra Firme forests (Circles) in the Araracuara region, Northwestern Colombian Amazon. 


\begin{tabular}{|c|c|c|c|}
\hline & Floodplain & Tierra firme & Total \\
\hline Species & $79(33.2 \pm 9.3)$ & $73(29 \pm 6.3)$ & 109 \\
\hline Mosses & $28(15.5 \pm 3.33)$ & $16(7.37 \pm 1.3)$ & 32 \\
\hline Liverworts & $51(18 \pm 7.1)$ & $57(21.6 \pm 6.1)$ & 77 \\
\hline \multicolumn{4}{|l|}{ Genera } \\
\hline Mosses & 20 & 9 & 20 \\
\hline Liverworts & 29 & 21 & 32 \\
\hline \multicolumn{4}{|l|}{ Families } \\
\hline Mosses & 11 & 6 & 11 \\
\hline Liverworts & 8 & 5 & 9 \\
\hline
\end{tabular}

Particularly the number of species reported in Guyana may be lower due to clumping of many species of tropical liverworts (Uribe \& Gradstein 1998). In the past bryophyte studies considered mosses and liverworts mostly as a group. However, they have shown recurrently different responses to environmental gradients. Different response of mosses and liverworts have been found in the tropics in altitudinal transects (Wolf 1993), successional stages (Acebey et al. 2003), humidity gradients (Florschütz-de Waard \& Bekker 1987), habitat types (Reenen \& Gradstein 1982) and vertical forest strata (Cornelissen \& ter Steege 1989, Montfoort \& Ek 1990).

The similarity in the bryophyte species richness observed was generated by opposite patterns in mosses and liverworts with more moss species in the floodplain and more liverworts in the tierra firme forest. The dominance of mosses in the floodplains may be explained by the dependence of moss growth to high humidity levels as has been reported for selected tropical mosses (Frahm 1987). Tropical lowland mosses have especially been found in humid landscapes (floodplains) in Surinam (Florschütz-de Waard \& Bekker 1987). The high species richness of liverworts in the tierra firme forest may be consequence of the endosporic germination of the spores (During \& van Tooren 1987) that allow liverworts to take advantage of ephemeral favorable environmental conditions such as the humidity after rain periods. They may become established in the new habitats by morphological structures to improve drought tolerance such as water sacs and physiological strategies to survive drought such as metabolism reduction (Furness \& Grime 1982, Proctor 2000).

The dominance of epiphytic bryophytes with overexposed life forms in the floodplains suggests higher humidity levels in the understory (Bates 1998). Also, epiphytic species require a constant moisture supply because the scant water-holding ability of tree barks (Nadkarni et al. 2000). The change observed mainly in moss species richness between the flooded and nonflooded landscape units is related with the absence of mat growing mosses and the dominance of weft growing liverworts in the tierra firme forest. Substrate availability and age have been considered to have a direct relation with epiphytic bryophyte diversity in temperate and tropical montane ecosystems (Acebey et al. 2000, Lyons et al. 2000). The changes in habitat use of bryophytes have been related with changes in the microclimatic conditions, like the change of terrestrial to epiphytic mosses in the wet forest of the Chocó region (Frahm 1994). Particularly, floodplains have a lower tree density than tierra firme forest and have almost the same tree basal area (Duque et al. 2001) indicating the presence of few aged trees with high diameter values in the floodplains. The reduction of epiphytic bryophytes and rotten wood cover by bryophyte species in the tierra firme forest may be related with the lower surface of tree bark 
exposed together with supposedly lower levels of humidity.

The different bryophyte composition in the understory of flooded and tierra firme forests are indicative of the different environmental characteristics of both landscape units. Even more, flooding has been reported to cause an effect on vascular plant composition and structure (Duque et al. 2001). Forest structure also has an effect on microclimatic conditions such as humidity, radiation, temperature and wind speed (Richards 1996). The combination of the microclimatic factors and substrate availability may explain different composition of bryophytes between the flooded and non flooded forest. The different bryophyte composition between flooded and non flooded landscape units in Northwestern Amazonia has also been found in the middle Caquetá and Chiribiquete areas, comprising an area of about $1000 \mathrm{Km}^{2}$ (Duque in prep.). The main change in bryophyte composition is observed in facultative epiphytes and true epiphyte mosses such as the absence of the Andean family Pilotrichaceae in the tierra firme forests and the presence of several species of Syrrhopodon in the tierra firme forest. The genus Syrrhopodon has special morphological features for drought evasion. They have hyaline water holding cells in the leaf base and high dispersal ability by means of vegetative propagules (Churchill 1994).

Interesting, epiphylls did not show the strong environmental preferences observed in the other bryophyte habits. The surface of living leaves has been considered an extreme substrate with high exposition to light and wind (Coley et al. 1993). Epiphylls in the lowland rain forest have been found affected mainly by light intensity (Lücking 1995). Low beta diversity of tropical rain forest epiphylls has been also found in foliicolous lichens with higher variation of the species assemblages in a given phorophyte than among different phorophytes (Lücking 1998).

Acknowledgments: The authors want to thank to Herbarium HUA, Fundación Tropenbos Colombia and IBED-Universiteit van Amsterdam for logistic support. J. Uribe helped with the identification of liverwort species. Prof. Antoine Cleef made important comments on the manuscript. This study was partially financed by Tropenbos-Colombia and the HuygensNUFFIC programme.

\section{References}

Acebey, A., Gradstein, S.R. \& Krömer, T. 2003. Species richness and habitat diversification of bryophytes in submontane rain forest and fallows of Bolivia. Journal of Tropical Ecology 19: 9-18.

Bates, J.W. 1998. Is „Life Form“ a useful concept in bryophyte ecology? Oikos 82: 23-237.

Bates, J.W. 2000. Mineral nutrition, substratum ecology, and pollution, pp. 403-448. In Shaw, A.J. \& Goffinet, B. (eds.), Bryophyte Biology. Cambridge University Press, Cambridge.

Casgrain, P. \& Legendre, P. 2002. The R Package for multivariate and spatial analysis. Version 4.0d6. Montréal, Université de Montréal.

Churchill, S. P. 1994. The mosses of Amazonian Ecuador. AAU Reports 35: 1-211.

Clark, K. L., Nadkarni, N.M. \& Gholz, H.L. 1998. Growth, net production, litter decomposition, and net nitrogen accumulation by epiphytic bryophytes in a tropical montane forest. Biotropica 30 : 12-23.

Coley, P.D., Kursar, T.A. \& Machado, J. 1993. Colonization of tropical rain forest leaves by epiphylls: effects of site, and host plant leaf lifetime. Ecology 74: 619-623.

Cornelissen, J. H. C. \& ter Steege, H. 1989. Distribution and ecology of epiphytic bryophytes and lichens in dry evergreen forest in Guyana. Journal of Tropical Ecology 5: 131-150.

Crosby, M. R., Magill, R.E. \& Bauer, C.R. 1992. Index of Mosses, 1963-1989. Monographs in Systematic Botany from the Missouri Botanical Garden 42.

Duivenvoorden, J.F. \& Lips, J.M.. 1995. A Landecological study of soils, vegetation and plant diversity in Colombian Amazonia. Tropenbos Series 12.

Duque, A., Sánchez, M., Cavelier, J., Duivenvoorden, J.F., Miraña, P., Miraña, J. \& Matapí, J. 2001. Relación bosqueambiente en el medio Caquetá, Amazonía Colombiana, pp. 99-130. In 
Duivenvoorden, J.F., Balslev, H., Cavelier, J., Grandez, C., Tuomisto, A. \& R. Valencia (eds.), Evaluación de recursos vegetales no maderables en la Amazonía noroccidental. Amsterdam. IBED. Universiteit van Amsterdam.

During, H.J. \& van Tooren, B.F.. 1987. Recent developments in bryophyte population biology. Trends in Ecology and Evolution 2: 89-93.

Florschütz-de Waard, J. \& Bekker, J.M. 1987. A comparative study of the bryophyte flora of different forest types in west Suriname. Cryptogamie, Bryologique et Lichénologique 8: 31-45.

Frahm, J.P. 1987. Which factors control the growth of epiphytic bryophytes in tropical rainforests? Symposia Biologica Hungarica 35: 939-648.

Frahm, J.P. 1994. A contribution to the bryoflora of the Chocó region, Colombia. I. Mosses. Tropical Bryology 9: 89-110.

Furness, S. P. \& Grime, J.P. 1982. Growth rate and temperature responses in bryophytes. Journal of Ecology 70: 525-536.

Gradstein, S. R. 1992a. The vanishing tropical rain forest as an environment for bryophytes and lichens, pp. 232-256. In J.W. Bates \& A.M. Farmer (eds.). Bryophytes and lichens in a changing environment. Oxford: Clarendon Press.

Gradstein, S. R. 1992b. Threatened bryophytes of the neotropical rain forest: a status report. Tropical Bryology 6: 83-93.

Gradstein, S. R., Churchill, S.P. \& Salazar-Allen, N. 2001. A guide to the bryophytes of tropical America. Memoirs of the New York Botanical Garden 86.

Gradstein, S. R. \& da Costa, D.P. 2003. The liverworts and hornworts of Brazil. Memoirs of the New York Botanical Garden 88.

Gradstein, S. R. \& Pócs, T. 1989. Bryophytes. In Lieth, H. \& Werger, M.J.A. (eds.), Tropical Rain Forest Ecosystems. Ecosystems of the World 14B.

Hietz, P., Wanek, W., Wania, R. \& Nadkarni, N.M.. 2002. Nitrogen-15 abundance in a montane cloud forest canopy as an indicator of nitrogen cycle and epiphyte nutrition. Oecologia 131: 350-355.

Kessler, M. 2000. Altitudinal zonation of Andean cryptogamic communities. Journal of Biogeography 27: 275-282.
Legendre, P. \& L. Legendre. 1998. Numerical ecology. Developments in Environmental Modeling 20.

Lips, J. \& Duivenvoorden, J.F. 2001. Caracterización ambiental, pp. 19-46. In Duivenvoorden, J.F., Balslev, H., Cavelier, J., Grandez, C., Tuomisto, A. \& R. Valencia (eds.), Evaluación de recursos vegetales no maderables en la Amazonía noroccidental. IBED, Universiteit van Amsterdam, Amsterdam.

Londoño, A. C. \& Alvarez, E. 1997. Composición florística de dos bosques (Tierra firme y Varzea) en la región de Aracuara, Amazonia Colombiana. Caldasia 19: 431-463.

Lücking, A. 1995. Diversität und Mikrohabitatpräferenzen epiphyller Moose in einem tropischen Regenwald in Costa Rica unter besonderer Berücksichtigung der Familie Lejeuneaceae. Ph.D. Dissertation. Ulm: Abteilung Spezielle Botanik, Universität Ulm.

Lücking, R. 1998. Ecology of foliicolous lichens at the „Botarrama“ trail (Costa Rica), a neotropical rain forest site. Part II. Patterns of diversity and area cover, and their dependence on microclimate and phorophyte species. Ecotropica 4: 1-24.

Lyons, B., Nadkarni, N.M. \& North, M.P. 2000. Spatial distribution and succession of epiphytes in Tsuga heterophylla (western hemlock) in an old-growth Douglas-fir forest. Canadian Journal of Botany 78: 957 968.

Mägdefrau, K. 1982. Life-forms of bryophytes, pp. 45-58. In Smith, A.J.E. (ed.), Bryophyte Ecology. Chapman \& Hall, London.

Montfoort, D. \& Ek, R.C. 1990. Vertical distribution and ecology of epiphytic bryophytes and lichens in a lowland rain forest in French Guiana. PhD Thesis. Utrecht: Institute of Systematic Botany.

Nadkarni, N. M., Cobb, A.R. \& Solano, R. 2000. Interception and retention of macroscopic bryophyte fragments by branch substrates in a tropical cloud forest: an experimental and demographic approach. Oecologia 122: 60-65.

Nieder, J. \& Zotz, G. 1998. Methods of analyzing the structure and dynamics of vascular epiphyte communities. Ecotropica 4: 3339.

Parker, G.G. 1995. Structure and microclimate of forest canopies, pp. 73-106. In M. Lowman 
\& N. M. Nadkarni (eds.), Forest canopies. Academic Press, San Diego.

Pócs, T. 1982. Tropical forest bryophytes, pp. 59104. In A.J.E. Smith (ed.), Bryophyte Ecology. Chapman \& Hall, London.

Proctor, M. C. F. 2000. The bryophyte paradox: tolerance desiccation, evasion of drought. Plant Ecology 151: 41-49.

Richards, P. W. 1984. The ecology of tropical forest bryophytes, pp. 1233-1270. In Schuster, R.M. (ed.), New Manual of Bryology. Hattori Botanical Laboratory, Nichinan.

Richards, P. W. 1996. The tropical rain forest, 2nd ed. 599 pp. Cambridge University Press, Cambridge.

Sokal, R. R. \& Rohlf, F.J. 1995. Biometry: the principles and practice of statistics in biological research, 3rd edition. $880 \mathrm{pp}$. W. H. Freeman and Co, New York.

Stuntz, S., Simon, U. \& Zotz, G. 2002. Rain forest air-conditioning: the moderating influence of epiphytes on the microclimate in tropical tree crowns. International Journal of Biometeorology 46: 53-59.

Uribe, J. \& Gradstein, S.R. 1998. Catalogue of the Hepaticae and Anthocerotae of Colombia. Bryophytorum Bibliotheca 53.

Wolf, J.H.D. 1993. Diversity patterns and biomass of epiphytic bryophytes and lichens along an altitudinal gradient in the northern Andes. Annals of the Missouri Botanical Garden 80: 928-960.

Zotz, G. \& Vollrath, V. 2003. The epiphyte vegetation of the palm Socratea exorrhiza correlation of tree size, tree age and bryophyte cover. Journal of Tropical Ecology 19: 81-90. 